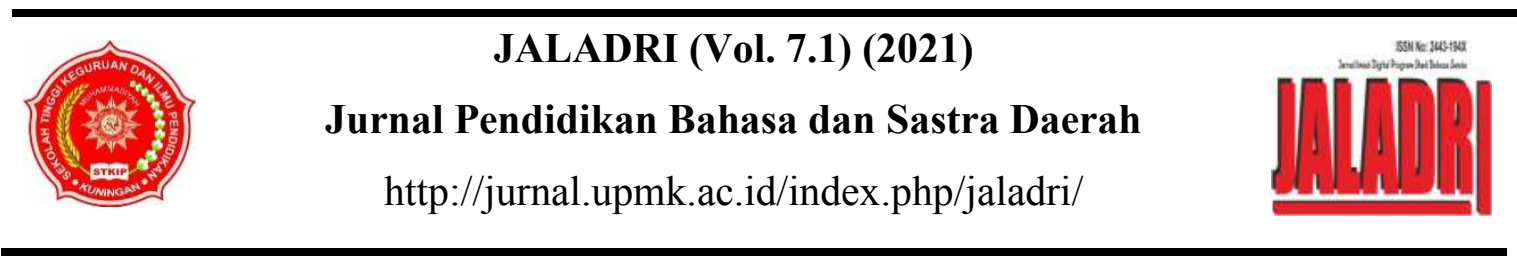

\title{
STRUKTUR DAN PERSPEKTIF BIOGRAFIS \\ DALAM BUKU KUMPULAN SAJAK JEMPLANG BULAN ILANG KARYA DIAN HENDRAYANA
}

\section{Rizal Firdaus}

rizalfirdaus722@gmail.com

Guru Bahasa Sunda SMK Negeri 4 Bandung

\section{Info Artikel}

Sejarah Artikel:

Diterima 10 Januari 2021

Disetujui 10 April 2021

Dipublikasikan 25 April 2021

\section{Kata Kunci:}

sajak;

struktur;

perspektif

biografis.

\begin{abstract}
Abstrak
Penelitian ini dilatarbelakangi oleh kurangnya pengetahuan masyarakat (umum) terhadap karya sastra Sunda, baik terhadap karya maupun pengarangnya. Tujuan penelitian ini untuk mencari struktur sajak yang ada dalam buku kumpulan sajak Jemplang Bulan Ilang, perspektif biografis pengarangya, dan kesesuaian antara perspektif biografis dan hasil analisis strukur sajaknya. Penelitian ini menggunakan metode deskriptif analitik dengan instrumen kartu data, alat rekam, kamera dan pedoman wawancara. Untuk proses analisis data digunakan tekinik studi pustaka, analisis langsung dan wawancara. Berdasakan hasil penelitian diperoleh hasil yaitu (1) struktur sajak yang terdiri atas diksi, imaji, simbol, wirahma atau musikalitas, suasana, tema dan gaya bahasa. (2) perspektif biografis pengarang yang meliputi riwayat hidup pengarang dan kedudukan sosialnya. (3) kesesuaian antara perspektif biografis pangarang dan hasil analisis struktur sajaknya. Artinya kehidupan sosial pengarang memiliki kesesuaian dengan karyanya.
\end{abstract}


Key Words:

poetry; structure;

biographical

perspective.
This research is motivated by the general public's lack of knowledge of Sundanese literary work, the meaning in his work and its authors. This study includes the structure of poetry in the book collection of Jemplang Bulan Ilang poetry, the biographical perspective of the author, the suitability of the biographical perspective and the results of the analysis of the structure of the poem. This research uses descriptive analytic methods using data cards and interview guidelines as instruments. In the process of data analysis in this study used literature study techniques, direct analysis and interviews. In this case the results obtained are (1) the structure of the poem consists of diction, images, symbols, spirit or musicality, atmosphere, theme and style of language (2) the author's biographical perspective which includes the life history of the author, and his social position. The next one gets results (3) the compatibility between the biographical perspective of pangarang and the results of the analysis of the structure of the poem. This means that the social life of the author has a match with his work. 


\section{PENDAHULUAN}

Tahun 2012, jagat sastra Sunda diperkaya dengan terbitnya buku kumpulan sajak Jemplang Bulan Ilang (JPI) karya Dian Hendrayana. Buku ini terbilang unik sebab dibentuk oleh kata-kata, gaya bahasa dan diksi yang penuh dengan makna dan estetika. Antologi sajak JPI memunculkan rasa yang membeludak dalam kegelisahan, selain itu, kehidupan romansa tergambar pula dalam antologi ini. Hal tersebut, menimbulkan rasa penasaran peneliti apakah sajak-sajaknya memiliki kesesuaian dengan kehidupan sosial dan pengalaman pengarangnya?

Agar dapat mengerti dan memahami isi sajak, tidak hanya sekedar memisahkan kata per katanya saja, tetapi harus dipahami secara menyeluruh. Dalam sajak, tentu memiliki unsur intrinsik sebagai pembentuknya, yang didukung oleh unsur-unsur struktur sajak. Hal inilah yang menjadi cara untuk menganalisis isi sajak, yaitu dengan cara menganalisis struktur yang terdapat dalam sajak tersebut. Salah satu kajian atau pisau analisis yang digunakan untuk menelisik karya sastra yaitu kajian struktural, pusat kajian struktur karya sastra itu sendiri.

Dilihat dari unsur intrinsiknya, sajak dibentuk oleh struktur fisik dan lapis makna. Aminudin (2014: 136) menuturkan bahwa struktur puisi merupakan unsur yang membentuk sajak yang dapat dilihat secara visual meliputi suara, kata, baris, paragraf, dan tipografi. Adapun lapis makna merupkan unsur yang tersembunyi dalam struktur.

Lahirnya karya sastra baik dalam bentuk puisi, prosa atau drama tidak terlepas dari penciptanya, sebab seperti dikatakan Suherman (2012) bahwa sastra merupakan produk interaksi sosial, antara pengarang dengan lingkungan sekitarnya. Abdillah (2017: 1) menuturkan bahwa karya sastra merupakan sebuah gambaran kehidupan (réalita sosial) yang dialami oleh pengarang lalu diréfléksikeun dalam bentuk karangan yang bersifat imajinatif.

Sastra lahir sebab adanya dorongandorongan dari rasa dan dan keinginan manusia untuk menjelaskan isi hati, pengalaman, dan keinginan untuk saling mempengaruhi terhadap manusia lainnya (Nuraliawati, 2014: 3)

Wallek \& Warren (1989: 88) dalam temuannya menuturkan bahwa ada hubungan dan kesamaan yang tidak langsung antara karya dan pengarangnya. Karya yang diciptakan pengarang bisa jadi merupakan topeng atau satu konvensi yang di dramatisasi berdasarkan pengalaman dan cerita hidup pengarang itu sendiri.

Dilihat dari isinya, sajak merupakan satu karya yang diciptakan oleh pengarang, melalui bahasa secara tulisan, untuk menyampaikan pikiran dan isi hati pengarang. Sastra sebagai salah satu lembaga sosial yang menggunakan bahasa sebagai mediumnya. Bahasa merupakan ciptaan sosial yang menjelaskan gambaran kehidupan masarakat, yang di dalamnya terkandung unsur budaya, dan seperti dikatan Dwiyanti (2019) bahwa unsur budaya ini menyebar dalam berbagai pranata yang ada di masyarakat.

Adapun kajian mengenai kehidupan masyarakat di antaranya melalui sosiologi, sebagai telaah ilmiah dan objektif untuk mengamati hubungan antara individu dan masyarakat, lembaga-lembaga, serta prosesproses sosialnya (Swingewood dalam Faruk, 1994: 1).

Menurut Wahyudi (2013: 1) secara umum sosiologi bisa diartikan sebagai salah satu telaah objektif mengenai manusia dan masyarakat yang meliputi proses-proses sosial di lingkungan sekitarnya.

Pada dasarnya sosiologi tidak ada kaitanya dengan sastra, sebab sosiologi merupakan titik awal dari disipin ilmu humaniora yang membahas mengenai masyrakat beserta lembaga dan proes sosialnya, sedangkan sastra merupakan hasil reka cipta yang memiliki hubungan erat dengan masyarakat. Oleh karena itu muncullah istilah "sosiologi sastra".

Pendekatan sosiologi merupakan pendekatan yang diharapkan dapat mengupas latar belakang lahirnya sebuah karya berhubungan dengan situasi kondisi tempat lahirnya karya tersebut. Menurut Damono (2013:10) pendekatan sosiologi memiliki arti yang sama dengan sosiologi sastra, yaitu pendekatan yang mempertimbangakan aspek kehidupan masyarakat, politik, ékonomi, sosial, budaya, réligi, dan adat istiadat.

Dalam penelitian ini, peneliti memusatkan penelitiannya pada apek biografis pengarang, atau pérspektif biografisnya.

Menurut Isnendes (dalam Ningrum. 2018: 2) sastra merupakan salah satu proses kreatif manusia dalam melahirkan karyanya. Oleh karena itu, hal ini berhubungan dengan pemikiran dan perspektif biografis pengarang. Kajian perspektif biografis merupakan bagian dari pendekatan ekstrinsik karya sastra yang menjelaskan atau membahas mengenai status 
sosial, ideologi politik, dan hal-hal yang berhubungan dengan pribadi pengarang.

Penelitian tentang perspektif bigrafis karya sastra telah banyak dilakukan, tapi penelitian yang lebih terpusat pada biografis pengarang sajak sunda masih jarang. Penelitian mengenai perspektif biografis pengarang pernah dilaksanakan. Salah satu judulnya yaitu "Perspektif Biografis dalam Novel Sabalakana Karya Dadan Sutisna (Kajian Sosiologi sastra)" (Fitriya Auliya Rachma, 2016). Perbedaan yang dapat dilihat dari penelitian ini yaitu objek yang menjadi pusat penelitian, yaitu novel dan sajak.

\section{METODE PENELITIAN}

Penelitian ini merupakan penelitian kualitatif dengan menggunakan métode déskriptif analitik. Penelitian kualitatif yaitu proses penelitian yang menghasilkan data déskriptif berupa kata-kata tertulis ataupun lisan yang berasal dari manusia serta tingkah lakunya yang dapat diteliti (Bogdan dan Taylor dalam Moleong, 2007: 4). Adapun deskripsi berarti menjelaskan mengenai satu hal, misalnya keadaan, kejadian, kegiatan, atau hal-hal lain, yang hasilnya dijelaskan dalam bentuk laporan penelitian (Arikunto, 2010: 3). Metode ini menggambarkan keadaan objek yang diteliti. Sesuai dengan apa yang dijelaskan oleh Ratna (2015: 53) bahwa metode deskriptif analitik merupakan cara mendeskripsikan fakta-fakta yang dilanjutkan dengan proses analisis.

\section{HASIL DAN PEMBAHASAN}

\section{Struktur Sajak Jemplang Bulan Ilang karya Dian Hendrayana}

Struktur sajak yaitu bagian-bagian yang membentuk sebuah sajak, struktur membentuk sajak secara menyeluruh Jayanti (2014: 2). Sebagaimana dengan apa yang telah dibahas sebelumnya, struktur atau unsur-unsur intrinsik yang ada pada sajak yaitu: 1) De-Kon (dénotatif dan konotatif), yang meliputi diksi; 2) isim yaitu imaji, simbol atau lambang, dan musikalitas atau wirahma; dan 3) STG, yaitu suasana, téma, dan gaya bahasa.

Buku kumpulan sajak Jemplang Bulan Ilang meliputi 46 judul sajak. Sajak yang dianalsis berjumlah 30 sajak. Berdasarkan data yang diteliti, terdapat adanya 7 unsur intrinsik atau sturktur yang membentuk sajak. Diantaranya yaitu diksi, imaji, simbol. Wirahma atawa musikalitas, suasana, téma dan gaya bahasa.

\section{Diksi}

Diksi merupakan pilihan kata untuk mewakili isi dari sajaknya yang bertujuan agar pembaca lebih mudah memahami isi sajaknya.

Kata-kata yang dipilih oleh penyajak bisa merupakan kata dénotasi (nyata) atau kakonotasi (lambang). Pilihan kata dalam sajak, kebanyakan memiliki sifat konotatif serta memiliki arti lebih dari satu dan merupakan kata yang puitis (indah).

Berdasarkan data yang dianalisis, terdapat 30 kata dalam 30 judul sajak yang mewakili isi dari sajak-sajaknya. Diantaranya terlihat pada kutipan sajak "Jemplang Bulan Ilang" dibawah ini

\section{Sajak JBI/JBI/24/36/01/02}

\section{"Bet di dieu seungit samoja nyambuang sapatengahan, hariweusweus nalatahkeun réwuan catetan kulawu"}

kata samoja menggambarkan ingatan, kata kulawu menunjukan sebuah kejadian yang kurang baik yang pernah dialami. Jadi, diksi dalam kalimat di atas menggambarkan ingataningatan dari masa lalu yang kurang baik untuk diingat kembali. Kata-kata di atas pantas untuk menggambarkan keadaan yang menyedihkan.

\section{Imaji}

Imaji erat hubungannya dengan diksi dan kata konkrit (nyata). Diksi yang dipilih haruslah menghasilkan imaji. Oleh karena itu, setiap kata menjadi lebih konkrit seperti yang biasa diresapi dari mata, telinga, atau cipta rasa. Waluyo (1995: 8) menuturkan bahwa imaji bisa dibatasi sebagai kata atau susunan kata yang dapat menggambarkan pengalaman sensoris, seperti penglihatan, pendengaran, dan rasa.

Berdasarkan hasil analisis, terdapat imaji dalam buku kumpulan sajak Jemplang Bulan Ilang yang meliputi imaji penglihat, imaji pandengar, imaji pencium, imaji rasa, dan imaji gerak. Tapi Imaji yang lebih sering muncul yaitu imaji rasa, seperti kata "sono", "simpé", "hiliwir", "jempling" dan sebagainya

Analisis salah satu imaji dilihat pada table dibawah ini: 
Tabel 1

\begin{tabular}{ccl}
\hline No & Kode & Imaji Pangrasa \\
\hline $\mathbf{1}$ & JBI/RRT/08/ & Simpé ku lagu \\
& $15 / 01 / 01$ & kamari \\
\hline
\end{tabular}

Berdasarkan hasil analisis di atas, kata simpé berarti sepi, sunyi dan tak terdengar suara apapun. Artinya, dalam sajak ini pengarang sedang merasakan keadaan sepi.

\section{Simbol}

Simbol yaitu peminjaman arti dari kata yang lain, dengan bertujuan untuk menjelaskan lebih dalam arti sajak yang dimaksud.

Berdasarkan hasil analisis, ditemukan 30 simbol dari 30 judul sajak yang dianalisis. Hal tersebut terlihat dari simbol yang digunakan oleh pengarang dalam sajak nomer 14 (Sinjang Réréng Garutan: Teu Nyana Enung Bet Miang) ditemukan dalam kalimat di bawah ini.

JBI/SRG/14/20/01/01

\section{Sinjang réréng garutan keur anteng ninun kakangen}

kata ninun memiliki simbol untuk menunjukan perasaan rindu yang tak kunjung usai. Jadi, dalam kalimat ini memiliki simbol sebagai rasa rindu dan sebuah harapan besar.

\section{Wirahma dan Musikalitas}

Kumpulan sajak Jemplang Bulan Ilang karya Dian Hendryana, dengan jumlah 30 judul sajak yang dianalisis dari 46 judul sajak, memiliki kata dan kalimat yang berirama atau murwakanti. Hal ini membuktikan bahwa katakata yang dipakai dalam buku kumpulan sajak Jemplang Bulan Ilang memiliki nilai estetis. Dari 30 judul sajak yang dianalisis, diperoleh ada dua jenis purwakanti dari sepulu purwakanti, yaitu purwakanti pangluyu dan purwakanti mindoan wekas seperti contoh kalimat dibawah.

Tabel 3

\begin{tabular}{lll}
\hline No & Kode & Purwakanti
\end{tabular}

\begin{tabular}{lll} 
& & \multicolumn{1}{c}{ Pangluyu } \\
\hline 1. & JBI/JTGS/ & Tur érmawar \\
& $\mathbf{0 3 / 0 9 / 0 2 /}$ & nu kedahna \\
& sumedeng ligar \\
\hline
\end{tabular}

pada kalimat diatas, dapat dilihat bahwa kata érmawar dan kata ligar memiliki suara vokal yang sama yaitu "a". dalam kalimat ini menunjukan bahwa bunga yang mekar adalah bunga yang tumbuh.

\section{Suasana}

Suasana yaitu gambaran keadaan yang mewakili tema. Dari gambaran atau keadaan isi sajak, pembaca akan mengetahui perasaan yang sedang dialami penyajak. Misalnya sebuah sajak mimiliki tema tentang rasa sakit, suasananya tidak mungkin menggambarkan kegembiraan, tentu saja suasana sedihlah yang tergambar dalam sajak tersebut.

Berdasarkan hasil analisis, didapat suasana sengsara, bingung dan berharap besar. Hal tersebut dapat dilihat dari salah satu contoh dibawah.

Tabel 4

\begin{tabular}{ccc}
\hline No & \multicolumn{1}{c}{ Kode } & Suasana Nelangsa \\
$\mathbf{1}$ & JBI/JTGS/ & Jempling beuki \\
\hline $\mathbf{0 3 / 0 9 / 0 2}$ & kerep ngabakutet \\
& létah \\
\hline
\end{tabular}

Kata ngabakutet létah menunjukan keadaan sepi yang selalu membangunkan ingatan-ingatan dan rasa rindu penulis.

\section{Tema}

Tema yaitu inti pikiran atau pusat bayangan pengarang. Terdapat di seluruh isi puisi, tampak terasa (oleh pembaca) dari awal hingga akhir (Sudaryat, 2015, hlm. 150). Seringkali tema tidak nampak secara langsung, tapi tersembunyi dari keseluruhan susunan bahasa. Oleh sebab itu, selalu disimpulkan oleh pembaca. Adapun macam-macam tema diantaranya: tema keagamaan, tema kemanusiaan, tema patriotisme/kebangsaan, tema kedaulatan rakyat, dan tema keadilan sosial.

Kumpulan sajak Jemplang Bulan Ilang karya Dian Hendryana, dari 30 judul sajak yang dianalisis, memiliki tema Cinta. Hal tersebut dapat dilihat dari beberapa isi sajaknya yang 
menggambarkan rasa cinta. Tergambar dalam sajak yang menjadi judul utama yaitu sajak jemplang bulan ilang.

\section{Gaya Bahasa}

Gaya bahasa yaitu bahasa yang diucapkan penulis untuk mengungkapkan satu hal dengan cara yang tidak biasa, secara tidak langsung dalam mengungkapkan maknanya. Kata atau bahasanya memiliki makna kias atau makna lambang. Fungsi penting dari bahasa figuratif (majas) yaitu memiliki dua makna dan dua acuan, tapi setelah dihubungkan satu sama lain memunculkan arti baru.

Berdasarkan hasil analisis, terdapat tiga gaya bahasa yang digunakan dalam buku kumpulan sajak Jemplang Bulan Ilang, diantaranya gaya bahasa lalandian, mijalma, dan kadalon. Tapi yang seringkali muncul yaitu gaya bahasa mijalma . hal tersebut dapat dilihat pada contoh dibawah.

Tabel 5

\begin{tabular}{cc}
\hline No $\quad$ Kode & Gaya Bahsa Mijalma \\
1. JBI/RRT1// & piring jeung \\
$\mathbf{0 8 / 1 4}$ & $\begin{array}{l}\text { gelasna } \\
\text { nyatetkeun kalaip } \\
\end{array}$ \\
& diri \\
\hline
\end{tabular}

Kata nyatetkeun, biasanya digunakan untuk pekerjaan manusia yang sedang menulis atau menuliskan suatu pekerjaan.

\section{Pérspektif Dian Hendrayana Dalam Buku Kumpulan Sajak Jemplang Bulan Ilang}

\section{Riwayat Hidup Dian Hendrayana}

Dian Hendrayana (DH), lahir di Subang 25 Februari 1971. Lahir disebuah keluarga yang sederhana, ibunya Siti Romlah dan Ayahnya yang menyukai seni yaitu $\mathrm{R}$ Sukendar merupakan sebuah latar belakang yang akhirnya menjadikan DH unggul perihal seni dan sastra.

DH menyelesaikan pendidikannya di SDN 1 Tanara Pangaléngan sebab saat di Subang DH hanya sekolah sampai kelas 2 SD. Sejak saat itu DH sangat sering diajak oleh ayahnya untuk menonton pertunjukan seni. Bahkan ia sempat terjun langsung dalam kesenian Jaipongan. Selain gemar dalam berkesenian, DH tertarik oleh kesusastraan khususnya sastra Sunda. Hal tersebut juga diturunkan dari sang ayah yang memiliki latar belakang gemar dalam menulis sajak atau cerpen. R Sukendar sebagai ayahnya, pada saat itu bekerja di sebuah perusahaan perkebunan yang memiliki majalah intern. Yang menjadi penyebab DH tertarik pada dunia sastra, awalnya sering membaca sajak-sajak dan cerpencerpen yang ditulis sang ayah. Selain itu, pada suatu hari DH pernah jatuh sakit hingga dirawat selama 20 hari di rumah sakit. Setiap hari DH selalu dibawakan majalah mangle oleh ayahnya. Untuk menghilangkan rasa kesal, semenjak itulah DH mulai tertarik pada sastra Sunda khususnya cerita-cerita karya Rahmatulloh Ading Affandi atau RAF. Karya RAF yang sering dibaca kala itu adalah cerita bersambung $\mathrm{Nu}$ Kaul Lagu Kaléon. Walaupun tidak mengerti seluruhnya isi dari cerpen tersebut, tapi karena kekayan bahasanya. Pada saat itulah DH memiliki pemikiran bahwa sastra Sunda memiliki wadah untuk imajinasi-imajinasi yang sangat luas. Sejak saat itulah DH gemar dan senang sekali membaca mangle, menulis dan berkesenian.

\section{Status Sosial Dian Hendrayana}

\section{Dian Hendrayana dan Organisasi}

DH pertama kali terjun dalam dunia organisasi ketika masuk kuliah di Unpad tahun 1990. DH bergabung di Studi Budaya Sunda Rawayan yang memiliki tujuan dalam bidang seni, sastra dan budaya Sunda. Hal itu menumbuhkan kecintaan DH terhadap bidang teater dan diskusi sastra. Dalam bidang seni DH juga turut bergabung dalam organisasi Lingkung Seni Sunda Unpad (Lises Unpad). Dari situlah awal mula DH tertarik pada bidang seni Cianjuran. Pernah pada suatu hari DH menemukan kaset Cianjuran, dimana juru tembang dalam kaset tersebut adalah Yus Wiradireja, DH sangat tertarik terhadap suaranya yang amat merdu, yang ahirnya membawa DH menjadi sangat mengidolakan Yus Wiradireja. Selain tertarik oleh kemerduan suara juru tembangnya, DH juga tertarik oleh lirik lagunya yang ditulis Eddy D Iskandar. Hingga pada akhirnya DH memutuskan untuk bergabung dengan organisasi Daya Mahasiswa Sunda (Damas) yang kebetulan aktif dalam bidang seni Cianjuran.

Setelah aktif di Damas, taun 1996-1998 DH diangkat menjadi ketua Damas cabang Kota Bandung yang selanjutnya mengantarkan DH aktif di Damas tingkat pusat dan Korps Alumni Damas. Hingga saat ini DH masih aktif dalam 
kegiatan-kegiatan organisasi seperti PPSS dan LBSS.

\section{Dian Hendrayana dan Pekerjaan}

Tahun 1997 DH menyelesaikan studinya di Unpad. Karena DH tergolong mahasiswa yang aktif dalam hal menulis, serta tulisanya telah dikenal oleh masyarakat DH langsung mendapatkan pekerjaan di perusahaan percétakan buku Grafindo sebagai editor. 2 tahun bekerja sebagai editor. Karena pada saat itu terjadi krisis moneter, akhirnya menyebabkan DH di PHK. Selanjutnya DH mencoba mengikuti seleksi untuk menjadi wartawan di Metro Bandung (sekarang Tribun Jabar). DH bertugas sebagai wartawan kriminal tahun 1999 sampai tahun 2003.

Tahun 2003 DH keluar dari Metro Bandung dan memutuskan untuk melanjutkan studinya. Dalam perjalanan melanjutkan studinya, DH hanya bertahan satu tahun yang selanjutnya pada tahun 2004, DH kembali bekerja sebab di tahun tersebut $\mathrm{DH}$ merasa banyak kebutuhuan yang harus dipenuhi. Terlebih lagi DH telah menjalani kehidupan rumah tangga sejak Februari 2003.

Tahun 2004 DH kebetulan diajak ikut merintis berita bahasa Sunda pertama di TVRI oleh Us Tiarsa (Mantan Ketua LBSS). DH tergolong orang yang ikut serta mencatatkan sejarah dalam perkembangan berita bahasa Sunda saat itu. Namun sayangnya DH hanya bertahan satu tahun di TVRI. Sebab pada saat itu Us Tiarsa tiba-tiba memboyong DH hijrah ke salah satu stasiun TV baru yaitu Bandung TV.

Keluar dari TVRI tahun 2004 lalu ikut merintis Bandung TV, hingga saat itu Bandung TV menjadi salah satu stasiun TV terbaik perihal berita bahasa Sunda. Kata-kata dalam menyampaikan beritanya pun hingga saat ini masih digunakan bahkan menjadi template untuk berita bahasa Sunda di beberapa statiun TV lokal.

Di Bandung TV terbilang cukup lama, bahkan DH sempat menjadi pimpinan produksi acara Dalingding Asih hingga acara tersebut menjadi salah satu acara favorit pada jamannya. Tahun 2009 DH keluar dari Bandung TV melanjutkan studi S2 di Sekolah Pascasarjana UPI jurusan Pendidikan Budaya Sunda hingga tahun 2011 yang akhirnya mengantarkan DH untuk mengemban tugas sebagai Dosen di Jurusan Pendidikan Basa Sunda UPI sampai sekarang.
Pengaruh Tokoh-tokoh pada Kehidupan Dian Hendrayana di dalam Karya-karyanya

Sebagaimana dengan apa yang telah dibahas sebelumnya, DH tergolong kedalam orang yang aktif dalam kegiatan organisasi, menulis, dan berkesenian. Dalam kehidupan DH, ada beberapa tokoh yang mempengaruhi terhadap lahirnya karya-karyanya khususnya yang berhubungan dengan buku kumpulan Sajak Jemplang Bulan Ilang. Dalam dunia sastra, tokoh $\mathrm{R}$ Sukendar yaitu ayahnya merupakan salah satu tokoh yang paling penting yang mempengaruhi terhadap proses kréatif DH. Sebab Sukendar merupakan orang pertama yang memperkenalkan DH pada dunia sastra dan seni. Yang selanjutnya mengantarkan DH mengenal karya-karya Rahmatulloh Ading Affandi atau yang kita kenal sebagai RAF.

RAF merupakan tokoh yang berperan penting dalam keberlangsungan kehidupan $\mathrm{DH}$ yang begitu puitis. Hal tersebut dapat diamati di beberapa judul karyanya, kekayaan akan gaya bahasa, diksi dan imaji. RAF dianggap tokoh yang memiliki daya imaji serta kekayaan dalam penggunaan bahasa Sunda. Hal tersebutlah yang paling mempengaruhi terhadap gaya sastra $\mathrm{DH}$. DH merasa bahwa pengaruh RAF terhadap karya-karyanya hingga saat ini sangatlah besar.

Selanjutnya, dalam bidang seni Cianjuran, ada tokoh Yus Wiradireja,Wahyu Wibisana, dan Eddy D Iskandar yang ikut serta mempengaruhi karya-karya DH. Karya-karya bukan berupa musik tapi dalam bentuk lirik lagu. Lirik lagu yang diciptakan 3 tokoh diatas begitu disukai DH yang akhirnya mempengaruhi karya-karya DH yang sempat ia tulis

Selain tokoh-tokoh di atas, ada beberapa tokoh lainnya yang ikut serta mempengaruhi terhadap lahirnya karya-karya DH. Khususna tokoh-tokoh perempua yang bisa disebut pernah menjalin hubungan dekat dengan DH. Ada beberapa tokoh perempuan yang tidak bisa disebutkan namanya. Namun beberapa tokoh perempuan tersebut pernah muncul dalam beberapa judul karyanya serta menjadi bahan inspirasi DH dalam menulis karya-karyanya.

Pengalaman Hidup Dian Hendrayana Yang Berpengaruh Terhadap Karya-karyanya.

Pengalaman hidup atau perjalanan hidup seseorang dapat berpengaruh terhadap karyakarya yang dibuatnya. Dalam karya sastra, halhal tersebut menjadi wadah untuk menumpahkan imaji-imaji yang tidak terwadahi oleh karya 
lainnya. Begitupun DH yang karya-karyanya bayak dipengaruhi oleh pengalamanpengalamanya, baik pengalaman bahagia, ataupun sedih.

\section{Pengalaman Hidup Yang Getir}

Setiap manusia tentu memiliki pengalaman hidup yang getir. Sebab dalam kehidupan tak selamanya bertemu dengan kebahagiaan. Begitu pun dengan DH yang pernah mengalami hal-hal yang getir. Diantaranya, sempat di masa kuliahnya, DH menjalin hubungan dekat dengan seorang perempuan yang kebetulan merupakan teman kuliahnya di Unpad. DH menjalin hubungan sejak tahun 1992. Hubungan DH dan perempuan tersebut bisa dibilang sangat dekat, bahkan mendapat julukan deudeuh dan geugeut sebab sangat terkenal kedekatan hubungannya. Pada suatu hari, di tahun 1998 hubunganya terpaksa harus berakhir sebab wanita tersebut lulus lebih dulu serta orangtuanya meminta untuk segera dinikahkan.

Sejak saat itu DH mengalami masa-masa galaunya serta tak tahu apa yang harus ia lakukan.

Hingga pada tahun 2000, DH sudah tak saling berkabar lagi dengan wanita tersebut. Pada saat pertama kali bekerja di Métro Bandung, wanita tersebut datang kembali di kehidupan DH yang sudah tidak terlalu memikirkan wanita tersebut. Tahun 2001, DH mendapat kabar bahwa wanita tersebut akan menikah. Harapan DH untuk memiliki wanita tersebut semakin tipis. Akhirnya DH benar-benar mengahpuskan harapannya untuk dapat hidup bersama dengan wanita tersebut. Sejak saat itu, keduanya sudah tak lagi saling berkabar.

Tahun 2001-2003, Setelah lepas dari wanita tersebut, DH mulai menjadi pribadi yang cukup agresif dan dikabarkan dekat dengan beberapa wanita termasuk dengan salah satu rekan kerjanya di Metro Bandung sebagai wartawan. Lalu, di tahun 2000-an, DH pergi ke Malaysia yang membuat hubungannya dekat dengan seorang wanita bernama Lathifah. Bahkan nama Latifah pernah muncul di beberpa judul karyanya. Lalu ada nama Emay, yang dikenal lewat bukunya yang berjudul Surat Keur Emay, ternyata tokoh Emay juga pernah menjalin kedekatan dengan DH di kehidupan nyata.

Februari 2003, akhirnya DH mendapatkan jodohnya yaitu Antun Hikmawati yang merupakan salah satu rekannya di Jurusan Basa Sunda UPI semasa kuliah. Ketika akan mengakhiri masa lajangnya DH tiba-tiba mendapat kabar dari wanita yang dulu pernah menjalin hubungan dekat dengannya. DH semakin penasaran serta tak henti memikirkan wanita tersebut, siapakah gerangan yang tiba-tiba mengirimkan sms ucapan selamat ini? Akhirnya DH memberanikan diri. Tahun 2005 ketika lahir anak pertamanya, DH mencari kembali sms yang belum pernah dibalasnya waktu itu. Saking penasarannya DH akhirnya menemui wanita tersebut hingga akhirnya benar-benar mengakhiri hubungan diantara keduanya. Sebab waktu itu DH benar-benar merasa sakit hati, terlebih lagi kini DH sudah menjalani kehidupan rumah tangga bersama keluarga kecil yang bahagia.

Pengalam menyedihkan di atas, merupakan salah satu alur kehidupan DH yang hingga saat ini selalu ia simpan di laci ingatannya. Sebab menurut $\mathrm{DH}$, pengalamanpengalaman saperti itu sangat penting untuk disimpan dan dipelihara, sebab hal tersebut bisa jadi wadah insipirasinya untuk membuat sebuah karya di massa yang akan datang.

\section{Pengalaman Bahagia}

Jika DH pernah mengalami hal yang menyedihkan, tentu DH juga pernah mengalami hal yang sangat membahagiakan. Salah satunya yaitu ketika DH tergabung kedalam Damas serta bisa berbincang dengan idolanya Yus Wiradireja. Lalu ada juga pengalaman dimana DH bisa langsung berbincang dengan idolanya RAF.

Selanjutnya, pengalaman yang paling bahagia yaitu ketika lahir putra pertamanya di tahun 2005. DH sangat bahagia, sebab sebelumnya, Antun istrinya mengalami keguguran dua kali

\section{Perspektif Biografis Dian Héndrayana}

Berdasarkan hasil penelitian mengenai alur kehidupan Dian Héndrayana. Bisa dilihat bahwa ada beberapa pengalaman-pengalaman hidupnya yang berpangaruh kuat terhadap karya-karyanya. DH menyebutkan bahwa hal-hal menyedihkan yang pernah dialami olehnya, masih tersimpan rapih dalam ingatannya. Sebab hal tersebut bisa jadi wadah inspirasinya dalam menulis sebuah karya.

Selain itu, ilmu yang pernah $\mathrm{DH}$ dapatkan, baik ilmu sastra atau seni ketika bertemu dengan beberapa tokoh sastra seperti RAF, DAF, Wahyu Wibisana, Sukendar dan lain-lain benar-benar mempengaruhi $\mathrm{DH}$ terhadap cara-caranya dalam menuliskan katakata, diksi, imaji dan gaya bahasa dalam karyakaryanya, dimana gaya penulisannya hampir 
mirip dengan tokoh-tokoh tersebut. Hal terseut sangat jelas terlihat di beberapa judul sajak yang ada pada buku kumpulan sajak Jemplang Bulan Ilang.

Kesesuaian antara Alur Hidup Dian Hendrayana dengan Buku Kumpulan Sajak Jemplang Bulan Ilang

Persoalan pribadi DH yang mempengaruhi terhadap buku kumpulan sajak Jemplang Bulan Ilang yaitu pemikiran dan kegemarannya. Terlihat perihal pemikiran DH yang kritis. Utamanya, jika berhubungan soal kesenian, kesusastraan atau keadaan lingkungan sekitarnya. Terkait dengan kegemarannya yang begitu mencitai seni, khususna bidang seni cinjuran juga mempengaruhi terhadap bentukbentuk sajaknnya yang ada dalam buku kumpulan sajak Jemplang Bulan Ilang. Hal tersebut dapat kita lihat dari bentuk-bentuk sajaknya yang bercerita serta mendayu-dayu ibarat lagu-lagu Cianjuran.

\section{1) Pemikiran}

Sebagaimana yang telah dibahas dalam biografis pengarang, DH lahir di lingkungan keluarga yang mana ayahnya $\mathrm{R}$ Sukendar merupakan seorang pelaku seni dan sastra. Berdasarkan hasil wawancara dan dilengkapi oleh sumber tetulis lainnya, DH terbilang sebagai seorang yang kritis serta memiliki pemikiran yang visioner khususnya berkaitan dengan seni dan sastra Sunda juga terhadap keadaan lingkungan sekitarnya.

Pemikiran kritis DH mengenai keadaan lingkungan sekitarnya, dapat diamati ketika masa kuliahnya di Unpad, dimana lokasinya berada di sekitar Kota Bandung.

"Ari sabab ieu téténjoan teuing ku sareukseuk Kana pirang-pirang kekembangan nu patulayah maluguran sawan mangsa

Kapuragkeun ku angina-angin karbon ku hujanhujan laysol

Sarta bangkarakna wungkul jadi panonoban rupaning supa weureu”

(JBI/MNDB/01/07)

Kutipan sajak di atas, sesuai dengan pemikiran kritis DH mengenai keadaan lingkungan di sekitarnya. Hal tersebut juga dapa diamati di beberapa judul sajak lainnya yang berhubungan dengan keadaan sekitarnya. Bahkan DH benar-benar sangat kritis terhadap hal-hal kecil sekalipun. Hal tersebut sangat jelas terlihat ketika DH menyematkan imaji-imaji yang berhubungan dengan benda-benda mati yang bisa jadi dianggap hal yang tidak penting oleh orang lain. Contohnya seperti menyematkan diksi-diksi yang berhubungan dengan benda-benda kecil yang sering ia temui di sekitarnya.

\section{Bulan ukur ngaliwat dina padungdengan séndok garpuh}

(Sajak JBI/PMM/10/16/01/01)

Artinya, pemikiran DH sesuai serta memiliki pengaruh terhadap karya-karyanya. Khususnya dalam buku kumpulan sajak Jemplang Bulan Ilang.

\section{2) Kegemaran}

Berdasarkan hasil wawancara dan sumber tertulis lainnya. DH memiliki kegemaran di bidang sastra dan seni. Hal tersebut tentu sangat mempengaruhi karya-karyanya, khususnya yang ada dalam buku kumpulan sajak Jemplang Bulan Ilang. Di bidang seni DH sangat gemar terhadap seni Cianjuran. Hal tersebut sangat sesuai dan dapat diamati dalam beberapa judul sajaknya yang menyematkan kata-kata "hariring", "galindeng", dangding", "haleuang", "tembang" dan masih banyak lagi. Hal tersebut juga dapat kita amati di beberapa judul sajak dalam buku kumpulan sajak Jemplang Bulan Ilang.

\section{"Satuluyna, ngan kari hariring dangding atawa haleung tembang'}

(Sajak JBI/MNDB/01/07/01/02)

"Simpé ku lagu Kamari nu dihaleuangkeun dina réma-réma asma Robbi"

(Sajak JBI/RRT2/06/15/01/03)

Dapat kita amati, kutipan sajak di atas memiliki imaji yang dipengaruhi oleh kegemaran DH di bidang seni Cianjuran utamanya soal lagu atau bernyanyi. Kegemarannya terhadap Cianjuran tidak hanya digambarkan melalui imaji-imajinya. Tetapi terlihat juga dalam pola sajaknya yang mendayudayu seperti lagu-lagu Cianjuran. Kata-kata yang digunakan benar-benar menggambarkan personal DH yang memiliki kegemaran terhadap seni Cianjuran. 
Kesesuaian antara Kedudukan Sosial Dian Hendrayana dengan Buku Kumpulan Sajak Jemplang Bulan Ilang

Kehidupan sosial erat hubungannya dengan pekerjaan, kebiasaan, kejadian, keadaan sosial, serta proses keterkaitan antara DH dan lingkungannya yang sempat dialami dalam kehidupannya sebagaimana yang telah didapatkan dari hasil analisis struktur sajak dalam buku kumpulan sajak Jemplang Bulan Ilang.

Ada beberapa persoalan yang sesuai antara kejadian hidup yang pernah dialami DH dan hasil analisis struktur sajak dalam buku kumpulan sajak Jemplang Bulan Ilang. Di antaranya mengenai gaya menulisnya yang kebanyakan dipengaruhi oleh RAF setelah DH sering membaca karaya-karyanya dan sempat dipertemukan serta diberi ilmu mengenai menulis yang hingga saat ini mempengaruhi karyakaryanya, khsusnya dalam buku kumpulan sajak Jemplang Bulan Ilang. Ada pula kesesuaian lainnya dari kajadian-kajadian ketika DH kuliah hingga bekerja di stasiun TV berupa sajak yang menceritakan kesedihan DH dalam kehidupan romansanya saat itu. Hal-hal tersebut akan dijelaskan pada pembahasan dibawah.

\section{1) Pengaruh Organisasi}

Sesuai dengan penjelasan yang dibahas dalam kedudukan sosial $\mathrm{DH}$, dan organisasi, DH pertama kali aktif dalam kegiatan organisasi ketika kuliah di Unpad tahun 1990. Walaupun DH lulus kuliah tahun 1997, DH masih aktif di organisasi kampusnya hingga tahun 2001. Salah satunya di LISES Unpad, pernah pada suatu hari di tahun 1999, DH jadi delegasi tim kesenian Lises Unpad untuk tampil di Malaysia. Hal tersebut sesuai dengan beberapa judul sajaknya yang ada dalam buku kumpulan sajak Jemplang Bulan Ilang.

Ah. Bulan urang eunteup lebah munara Petronas, Latifah.

Kualalumpur, 1999

(Sajak JBI/KL/18/35/01/02)

Satemena bulan luhureun kuala lumpur teu jauh béda jeung bulan luhureun ciawi.

(Sajak JBI/KL/18/35/01/02)
Kutipan sajak diatas menunjukan adanya kesesuaian antara pengalaman organisasi $\mathrm{DH}$ yang pernah pergi ke Malaysia tahun 1999 dengan sajak yang berlatar di Malaysia serta mimilki titimangsa tahun 1999. Artinya pengalaman oraganisasi $\mathrm{DH}$ berpengaruh terhadap karya-karyanya yang ada dalam buku kumpulan sajak Jemplang Bulan Ilang.

\section{2) Pengaruh Tokoh-tokoh}

Dalam menciptakan karyanya, khususna sajak-sajak yang ada dalam buku kumpulan sajak Jemplang Bulan Ilang, tentu ada tokoh-tokoh yang berpengaruh terhadap munculnya proses kreatif DH. Diantaranya ada tokoh sastrawan Rahmatulloh Ading Afandi. Sebagaimana yang telah dibahas sebelumnya. RAF memiliki peran penting terhadap munculnya karya-karya DH. Salah satunya sempat di suatu hari RAF memberikan saran kepada DH mengenai menyematkan imaji-imaji dan gaya bahasa dalam karya sastra. RAF menjelaskan bahwa segala hal yang tak bernyawa bisa bernyawa dalam karya sastra. Bisa jadi gorden yang setiap hari terlihat melambai sedang bercengkrama dengan hembusan angin. RAF juga memberikan saran kepada DH agar lebih memperhatikan hal-hal kecil yang dianggap tidak penting oleh orang lain. Maksud hal-hal kecil tersebut, yaitu bendabenda tak bernyawa yang biasanya sering nampak disekitar kita. Saran RAF mengenai hal tersebut benar-benar melekat di pikiran $\mathrm{DH}$, bahkan karya sastranya mengandung hal-hal yang sempat disampaikan oleh RAF saat itu.

Mancawura galeuh-galeuh deudeuh nu

kemu dina guligahna teuteupan karpét jeung suku méja

(Sajak JBI/RRT/08/14/01/02)

\section{Bulan ukur ngaliwat tina padungdengan séndok garpuh}

\section{Laju kapireng piring jeung gelasna nyatetkeun kalian diri}

\section{(Sajak JBI/PMM/10/16/01/02)}

Berdasarkan kutipan sajak di atas, dapat kita lihat bahwa ada kesesuaian antara pengaruh RAF dalam karya DH yang dibahas dalam hasil wawancara khususnya terhadap sajak-sajak DH 
yang ada dalam buku kumpulan sajak Jemplang Bulan Ilang.

\section{3) Pangalaman Hidup Yang Getir}

Selain dari pengaruh tokoh terhadap karya-karya $\mathrm{DH}$, yang berperan besar dalam lahirnya sajak-sajak yang ada dalan buku kumpulan sajak Jemplang Bulan Ilang, yaitu pengalaman hidup DH yang saat itu disebut menyedihkan. Berdasarkan hasil wawancara dan sumber tertulis lain, yang dibahas sebelumnya. DH menyebutkan bahwa sajak-sajaknya yang penyusun jadikan bahan penilitian merupakan sajak-sajak yang lahir dizaman kegalauannya. Dalam alur kehidupan DH, disebutkan bahwa DH pernah menjalin hubungan dengan seorang wanita di tahun 1993 yang terpakasa harus berakhir di tahun 1998. Yang selanjutnya memberikan harapan kemabali ketika DH bekerja sebagai wartawan, hingga akhirnya benar-benar berkahir di tahun 2003 sebab wanita tersebut akan dinikahkan dengan orang lain.

Ada 3 judul sajak dalam buku kumpulan sajak Jemplang Bulan Ilang yang ditulis di tahun 2003. Sajak tersebut berisi kesedihan DH karena ditinggalkan menikah oleh wanita yang dicintainya.

\section{(Sajak JBI/RRG/12/19/03/02)}

Sinjang Réréng Garutan: Teu Nyana Enung Bet Miang

Sanaos dikonci ditutup dirékép-rékép, geuning panon

engkang tara kabobodo ténjo. "lebah hambalan kadua,

handapeun kabaya nu pulas wungu, nya di dinya sinjang

réréng garutan keur anteng ninun kakangen."

Lah, tangtosna Enung mah moal uninga, saban usum muru

Pajuaran, nu karérét ku engkang mung ukur sinjang nu éta.

Pébuari, 2003

Kutipan sajak di atas, menunjukan rasa sedih yang mendalam saat itu. Artinya sajak di atas memiliki kesesuaian dengan alur hidup DH yang dijelaskan dalam hasil wawancara.

Rasa sedih juga terlihat ketika DH mendapat kabar bahwa wanita yang selama ini dicitainya akan dinikahkan oleh orangtuanya. Betapa sangat terpukulnya DH saat itu.

Leres aya iber kabaya wungu nu dianggo tadi wengi ku salira, majar cipruk kasawéran ku girimis. Bet di dieu, engkang kalah anteng nyileuk, bari nyawér-nyawérkeun girimis nu anteng medal tina panon sungapan kakangen.

Pébuari, 2003

\section{(Sajak JBI/SLP/12/25/02/03)}

Berdasarkan hasil wawancara mengenai alur hidup DH dan hasil analisis struktur, sajak diatas memiliki kesesuian, Februari 2003 DH merasakan kesedihan yang teramat dalam ketika mendapat kabar bahwa wanita yang dicintainya akan menikah dengan lelaki lain. Hal tersebut tergambar dalam kalimat nyawér-nyawérkeun girimis nu anteng medal tina panon sungapan kakangen.

Pada hakikatnya, sajak yang ditulis DH yang ada dalam buku kumpulan sajak Jemplang Bulan Ilang serta mimiliki titimangsa tahun 1999 sampai tahun 2003, merupakan sajak yang berisi ungkapan kesedihan DH yang ditinggal menikah oleh wanita kecintaannya. Artinya, pengaruh wanita tersebut terhadap karya-karya DH sesuai dengan sajak-sajak yang ada dalam buku kumpulan sajak Jemplang Bulan Ilang.

Dalam wawancara, DH juga menyebutkan, bahwa pada suatu ketika dirinya pernah mendapatkan pesan singkat dari wanita tersebut di penghujung tahun 2002, yang selanjutnya memunculkan kembali harapan $\mathrm{DH}$ kepada wanita tersebut. Namun, karena sudah terlanjur sakit hati, DH mengungkapkan serta membalas SMS wanita tersebut dengan kalimat "pan tos ulah aya kecap sono antawis urang".

\section{Kahatur Jungiunan Kalbu Keur N}

Saéna ulah aya kecap sono antawis urang. Mending palidkeun, urang palidkeun.

\section{KESIMPULAN}

Berdasarkan hasil analisis struktur, perjalanan hidup, status sosial, serta hasil wawancara mengenai pengalaman yang 
berhubungan dengan proses kréatif $\mathrm{DH}$ dalam menulis sajak yang ada pada buku kumpulan sajak Jemplang Bulan Ilang, bisa disimpulkan bahwa adanya korelasi antara sajak-sajak yang ada pada objek penelitian dan perjalanan hidup DH sebagai pengarangnya.

Kesesuaian tersebut dapat kita amati khususnya pada pengaruh tokoh RAF terhadap karya-karya DH dalam menggunakan imaji-imaji yang tak biasa, gaya bahasa yang begitu luas dan sebagainya korelasi lainnya yaitu antara kecintaan DH dalam témbang cianjuran yang digambarkan dalam sajak-sajaknya yang mengandung kata-kata haleuang, tembang, hariring, galindeng, dangding, kidung, dan lainlain.

Korelasi antara isi sajak dengan pangalaman menyedihkan DH dan juga kehidupan cintanya tergambar juga pada munculnya beberapa tokoh wanita pada sajaksajaknya serta kesesuaian pada titimangsa, isi sajak dan pengalaman yang dialami sejak kurun waktu tahun 1993 sampai tahun 2005.

\section{REFERENSI}

Abdillah, (2017). Darpan Jeung Réalita Sosial Masarakat. (Jurnal). Bandung: Pendidikan Kebudayaan Sunda. SPS UPI.

Aminudin. (2014). Sosiologi Sastra:Pengantar Teori Sastra. Jakarta: Gramedia.

Arikunto, S. (2010). Prosedur Penelitian Suatu Pendekatan Praktik. Jakarta: Rineka Cipta.

Damono, S. D. (2013). Sosiologi Sastra: Sebuah Pengantar Teori Sastra. Jakarta: Gramedia.

Dwiyanti, R., \& Suherman, A. (2019). Unsur Budaya Dalam Cerita Film Cakra Buana Karya Sutradara Massimo Burhanuddin. Lokabasa, 10(2), 204-213.

Farruk. (1994). Pengantar Sosiologi Sastra dan Strukturalisme Genetik Sampai Post Modernisme. Yogyakarta: Pustaka Pelajar.

Jayanti, D.A (2014). Kajian Struktutal-Semiotik Dina Buku Kumpulan Sajak Lagu Padungdung Karya Deni Ahmad Fajar Pikeun Bahan Pangajaran Maca Sajak Di SMA (Jurnal). Bandung: Departemen Pendidikan Bahasa Daerah.

Moleong, L. J. 2002. Metodelogi Penelitian Kualitatif. Bandung: Remaja Rosida Karya

Ningrum, (2013). Invéntarisasi Mantra Puisi di Kecamatan Situraja Kabupaten Sumedang (Ulikan Struktural), (Jurnal). Bandung: Departemen Pendidikan Bahasa Sunda.
Nuraliawati. (2014). Kapribadian Manusa Sunda dina Kumpulan Carita Pondok Ti Taun 1950-an nepi ka Taun 2000.

Ratna, N. K. (2014). Stilistika (Kajian Puitika Bahasa, Sastra, dan Budaya). Yogyakarta: Pustaka Pelajar.

Suherman, A. (2012). Potret Sosial Darpan.@ File Direktory UPI.

Suherman, A. (2017). Dalingding Bentang Hariring. @ File Direktory UPI.

Wallek, R., \& Warren, A. (1989). Teori kesusastraan: Terjemahan Melani Budiman. Jakarta: Gramedia.

Wahyudi, Tri. (2013). Sosiologi Sastra Alan Swingewood, Sebuah Teori (Jurnal). Yogyakarta: Fakultas Ilmu Budaya UGM. 